\title{
Miranda
}

Revue pluridisciplinaire du monde anglophone /

Multidisciplinary peer-reviewed journal on the English-

speaking world

$14 \mid 2017$

Early American Surrealisms, 1920-1940 / Parable Art

\section{Review of the exhibition Life on Mars David Bowie_Shot by Mick Rock}

Le Multiple, Toulouse, 2 December 2016-15 January 2017

Daniel Huber

\section{(2) OpenEdition}

Journals

\section{Electronic version}

URL: http://journals.openedition.org/miranda/10457

DOI: 10.4000/miranda.10457

ISSN: 2108-6559

\section{Publisher}

Université Toulouse - Jean Jaurès

\section{Electronic reference}

Daniel Huber, "Review of the exhibition Life on Mars David Bowie_Shot by Mick Rock", Miranda [Online], 14 | 2017, Online since 05 May 2017, connection on 16 February 2021. URL: http:// journals.openedition.org/miranda/10457 ; DOI: https://doi.org/10.4000/miranda.10457

This text was automatically generated on 16 February 2021

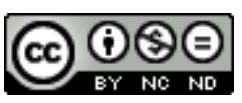

Miranda is licensed under a Creative Commons Attribution-NonCommercial-NoDerivatives 4.0 International License. 


\section{Review of the exhibition Life on Mars David Bowie_Shot by Mick Rock}

Le Multiple, Toulouse, 2 December 2016-15 January 2017

Daniel Huber

\section{"It's not who does it FIRST, it's who does it BEST." (David Bowie)}

1 Life on Mars David Bowie_Shot by Mick Rock_ was a hybrid exhibition presented at the collaborative and experimental multifunctional space Le Multiple ${ }^{1}$ in Toulouse, France, between 2 December 2016 and 15 January 2017: it combined various media from exquisite prints of photographs taken by Mick Rock through the glass showcases along the central axis of the exhibition space, containing original, and sometimes rare, contemporary documents coming from a private collection, to a video installation and the four testimonial citations, running along the walls, which are used here as section headings. The private collector is associated with Le Multiple and this collection formed the background to the images while Le Multiple, an old boilerworks, provided the exhibition space. The concept of showing documents related to photographs in an exhibition space has become standard practice over the past few years. Moreover, the exhibition sits definitely well in the wake of Total Records, shown in 2015 at the Rencontres d'Arles. ${ }^{2}$ It has been the first time for Rock's collection of photographs to be shown in France and it has quite possibly been the best way to be presented in this hybrid manner in such a unique space.

2 Mick Rock's photographs were a selection documenting David Bowie's spectacular rise in 1972-1973, from the perspective of the insider photographer functioning as the official photographer of the emerging star. ${ }^{3}$ Forty iconic shots of Bowie were exhibited, part colour, part black and white, together with one portrait of Mick Rock taken by his daughter Nathalie Rock in $2014^{4}$ which was hanging next to his introductory text ${ }^{5}$ dated 24 September 2016 and specially written to accompany the photographs on display in Toulouse. The photographs essentially derive from Rock's major and most recent book, 
The Rise of David Bowie 1972-1973, which Bowie co-signed with the photographer, comprising 200 photographs, published by Taschen in September 2015 in a limited and numbered edition, and then a trade edition, after Bowie's passing, for the general public in early 2016. However, there were nine prints on view that do not figure in the Taschen edition, therefore adding considerably to the uniqueness of the exhibition.

\section{"Mick sees me the way I see myself" (David Bowie)}

3 The exhibition presented Bowie as the facilitator between the worlds of art and science and the general public. This role of facilitator could be experienced on multiple levels. The world of art was present both through his music, evoked by the original vinyl albums, and Rock's photographs. The world of science was represented by references to space sciences in particular, such as the title of the exhibition, the futuristic designer costumes Bowie wore on stage as well as the video footages. The general public was both the contemporary audience in the concert halls, captured in thrill in some images, as well as today's visitors to the exhibition. All these aspects came out neatly in Rock's shots and were strengthened by the documents on display, driving the message home that David Bowie was a unique personality straddling and juxtaposing multiple universes of discourse.

In addition, Bowie's role as a facilitator was also reflected in the partnerships that went into the essentially grassroots organization of the show. Since the exhibition draws heavily on Bowie's fascination with the human conquest of outer space, as made obvious by titles such as Major Tom, Space Oddity, and, of course, Life on Mars?, it is coherent (and a great feat of organization!) that partners for this Toulouse exhibition included the Cité de l'Espace (City of Space) theme park in Toulouse and the CNES (Centre national d'études spatiales, National Centre for Space Studies) agency in Paris that generously provided video footage of the ongoing Mars mission. ${ }^{6}$ The university world was represented by the research laboratory CAS Culture Anglo Saxonnes of Toulouse 2 University that organized a one-day conference around David Bowie on 2 December 2016. ${ }^{7}$

\section{"All these moments would be gone forever if it wasn't for [Mick Rock]." (Lou Reed)}

Mick Rock was Bowie's friend for 44 years: his very first shot of Bowie, in Birmingham on 17 March 1972, was also on show as well as his last shot in New York in 2002. Mick Rock covered Bowie's rise to stardom performing as Ziggy Stardust (and later as Aladdin Sane), firmly established during his numerous gigs. The images were a balanced mix of concert photographs (Bowie alone or in interaction with fans), backstage and party snapshots and even private shots as well as stills from promotional material. The exhibition showed many images taken at concerts documenting his tour across the United Kingdom with The Spiders from Mars: on 17 March 1972 at Birmingham Town Hall, 12 May 1973 at Earls Court in London, 14-16 May 1973 at Aberdeen Music Hall, 15 June 1973 at the Taunton Odeon in London, 17 June 1973 at the Oxford Town Hall, 26 June 1973 at the Oxford New Theatre, 10 October 1973 in Liverpool and the Ziggy Stardust Farewell concert and after-party on 3 July $1973^{8}$. Rock also documented Bowie's first tour in the United States in images taken on 28 September 1972 in New 
York, going on to Los Angeles, 16-23 October 1972, then to San Francisco, 27 October 1972, and back to New York in December 1972. The latest, black and white, shot of Bowie by Rock at the exhibition, which shows Bowie wearing a black jacket and looking down, was also taken in New York, at the Milk Studios in 2002. It is a curious fact about the selection that only eight images had to do with the US tour, and even then there is one single image at concert, the others document the studio work and the set of The Jean Genie video. The material taken in the UK is more balanced and varied between concert shots, on-set stills and private images.

The title of the exhibition, Life on Mars, takes its cue from Bowie's song of that name. It represents a personal connection for Mick Rock because the track is on Hunky Dory (released in December 1971), the album he first listened to from Bowie: Felix Dennis, manager of $\mathrm{Oz}$ magazine, had offered him the promo album and the song was an immediate click (Rock 2016: 29). In May 1973, he directed the video for Life on Mars?. ${ }^{9}$ It is possibly significant from this perspective that the Taschen edition of 2015/2016 does not carry the shot where Bowie is holding the Hunky Dory album during the photo session at his home Haddon Hall in late March $1972^{10}$, but it was shown in Toulouse. There were additional 7 contemporary shots as well as the 2002 portrait that do not appear in the Taschen edition. All in all then, nearly a fourth of the material on display in Toulouse is not published in the Taschen edition.

7 While the captions in the Taschen edition and the exhibition catalogue generally match, sometimes it is the Taschen edition that gives more information about the circumstances of an image, sometimes it is the catalogue. On the one hand, for instance, the succinct caption for the image showing Bowie "putting his makeup on in front of a round mirror" is supplemented by this comment in Taschen: "Bowie usually did his own makeup and now was using a special Noh theatre palette, which he had brought back from his nine-gig Japanese tour in April 1973" (Rock 2016: 290). Or, to the image showing Bowie in the train from Kansas City to Los Angeles, 16-17 October 1972, Rock (2016: 294) adds that "Bowie is wearing the pink cap he favoured on tour when he decided not to style his hair". On the other hand, it is the catalogue that makes multiple references to the Japanese designer Kansai Yamamoto who, curiously, passes completely unnamed in the Taschen captions (although Rock evokes him in his interview with Barney Hoskyns). Furthermore, while the prints on display agree with the corresponding image in Taschen, two images are different: in the image showing Bowie in concert at the Empire Theatre (Liverpool, 10 October 1973), he is looking left while in the Taschen edition he is looking right; the image showing Bowie with a gold spot on his forehead at Earls Court, London, is teinted more blue and the spot is coloured gold, while it is plain black and white in Taschen, quite likely, simply because it is facing the monochrome contents page. Nevertheless, two major divergences between the two works remain: the caption to "Bowie showing owl eyes in performance" is dated May 1973, England, in the catalogue, but Manchester Hardrock, 29 December 1972, in Taschen (Rock 2016: 292); the black and white shot "live at the Aberdeen Music Hall" of 16 May 1973 in the catalogue is identical to an image dated 12 May 1973 at Earls Court, London, in Taschen (Rock 2016: 191, 295). In neither case does Bowie's costume help to decide, although the second costume resembles the one Bowie seems to be wearing at Fairfield Halls, Croydon, 24 June 1973 (Rock 2016: 73, 292).

Rock has shown his photographs of Bowie's in various museums, galleries and cultural centres across Europe and even in Hong-Kong, Shanghai and Japan, but this is the first 
time the images have been shown in France. However, Rock did not only photograph Bowie: indeed he created the most iconic images, not only of David Bowie, but of the pop scene of the 1970s. He shot over 100 album covers, including the iconic shots for Syd Barrett's Madcap Laughs (January 1970), Lou Reed's Transformer (November 1972), Iggy and The Stooges' Raw Power (February 1973), Queen's Queen II (March 1974) and Sheer Heart Attack (November 1974). He shot for Syd Barrett, Lou Reed, Iggy Pop, Queen, the Sex Pistols, Blondie among others in the 1970s and 1980s, and more recently Lenny Kravitz, Alicia Keys, Daft Punk, Lady Gaga or U2, for instance. ${ }^{11}$ In the interview with Barney Hoskyns for the Taschen edition, Rock confided that he got to know Bowie while he was working for the counter-culture magazine $O z$ (Rock 2016: 29). As for their professional relation, Bowie never told him how to photograph him, and it was the same with the videos: Bowie trusted him. Rock reports (2016: 30) that he told his manager that "Mick sees me the way I see myself", after reviewing the Haddon Hall photo session. Similarly, Lou Reed remembered (citation on the wall at the exhibition): "I like Mick and I like what he photographs, so shooting with him was never a problem. All these moments would be gone forever if it wasn't for him." As for Rock's inspiration to photograph all these people, he answered (Rock 2016: 30): "When people ask me what inspired me, it was really the charisma of a lot of my early subjects. It certainly wasn't other photographers." Throughout his career, Rock published a number of lavishly illustrated books of his photographs, of Lou Reed, Debbie Harry, Syd Barrett and Queen, as well as collections of his photographs of the Glam Rock era and the faces of rock'n'roll.

The privileged perspective of the insider photographer was particularly evident in a series of photographs. The shooting of Bowie at his home Haddon Hall, in Beckenham just outside London, in March 1972 definitely stands out. This session, quite early on in their relationship, produced some truly iconic images: the mirror shot made its way to the back cover and inner sleeve of the Pinups album of July 1973 and another was used on the sleeve of The US Space Oddity album (the 1972 US edition of the 1969 album). Further examples for Rock's privileged perspective are the shots taken on the set in the recording studio for the video of The Jean Genie in San Francisco in October 1972 and the particularly intimate shot showing Bowie with a single guitar in glittering clothes at the RCA Recording Studios in New York in December of that same year. Besides Life On Mars? ${ }^{12}$ and The Jean Genie $e^{13}$, Rock was also behind the music videos for John, I'm Only Dancing ${ }^{14}$ and Space Oddity ${ }^{15}$. There were numerous shots taken backstage, such as Bowie doing his makeup, getting dressed, performing his gig simulating a wrist slash, taking off his mask after concert, or praying before a concert.

Most images on view concentrated on Bowie alone: in 27 shots he is photographed alone, while only six photographs included at least one other member of his band, in five he is with some others and there were three shots of Bowie interacting with his fans. Party scenes are typically shot from a frontal perspective, from the point of view of the participants. Moments preserved on film from this stance included shots from the Ziggy Stardust Farewell party at the Café Royal in London on 4 July 1973, or at the party Bowie threw after his concert at the Carnegie Hall in New York on 28 September 1972, as well as the famous shot of David Bowie, Iggy Pop and Lou Reed together at the Dorchester Hotel, London, on 16 July 1972. The onstage shots of Bowie are often from an ant's eye view, that is from the point of view of the spectators or, occasionally, are taken on the stage. For the photographs on show, Rock had opted for a very efficient way of using colour and black and white prints: colours drew attention to the 
extravagant and daring palette of his makeup and dresses, while black and white emphasized the posture and the gestures. The photographs during concerts produced many iconic images, such as him making owl eyes or the famous guitar fellation with Mick Ronson at concert on 17 June 1972. The on-stage shots also made tribute to the costumes and stage-look Bowie meticulously chose for his stage presence and stage persona, Ziggy Stardust.

\section{“Maybe [Bowie] just wants to be Greta Garbo of Rock'n'roll" (Mick Rock)}

11 Bowie's fascination with fashion and colourful makeup, dyed hair, and masks was very aesthetically brought out by Rock's shots of him doing his makeup, or shots showing his stage costumes. For the video of Life on Mars?, shot on 12 May 1973, and the concert Bowie gave that night at Earls Court in London, Pierre Laroche created the makeup and Freddie Burretti ${ }^{16}$ the turquoise satin suit, all contributing to the glam rock look of the early 1970s. Burretti was behind the quilted jumpsuit Bowie wore on the UK TV show Top of the Pops ${ }^{17}$ on 14 April 1972. Laroche created the iconic Bowie stage-look of this period: the gold spot on his forehead, captured in a number of aesthetically balanced prints in the exhibition. Bowie changed clothes frequently during a concert and was thus wearing (and showing) numerous outfits also by the young Japanese designer Kansai Yamamoto on his tours, such as a Japanese cloak, various coats or his signature leotard and other pieces often inspired by kabuki theatre costumes. Rock's photographs go thus well beyond documenting Bowie's flamboyant stage presence, they also represent a valuable source for a Yamamoto lookbook: a designer collection shown while being actually worn. The Fashion Book (2014: 568) characterizes Yamamoto as the designer who "married traditional Japanese culture and Western influences, set them to a music beat and put them in the realm of the performing arts." Who better could carry this message than David Bowie? Elements of Yamamoto's style combined cartoon graphics and cotton netting or lush satin robes with large Japanese figures, as seen on many costumes worn by Bowie. It is by no means accidental in this context that Mick Rock later shot a whole series on kabuki costumes and theatre. ${ }^{18}$ Bowie's costumes designed by Burretti and Yamamoto accompanied the personas of Ziggy Stardust and Aladdin Sane.${ }^{19}$ Rock in his introductory text pointed out that, in knowingly managing his extravagant and flamboyant stage style, Bowie "made the androgynous hip" because "[h]e made it ok for men to reveal their softer side. Not just in their sexuality, but also in their sensory attitude." The overall effect of these visual statements was that of a futuristic creature dropped in the world of the early 1970s from some spaceship: the look of a glamorous alien.

\section{Further components of the exhibition}

The exhibition space was knowingly converted to the purpose. It contained design elements of photo shoots such as backdrops and projectors, the walls were painted red, and in places it was decorated with black and white stripes which echoed the stripes of the suit, designed by Burretti, Bowie wore on the train to Aberdeen on 14 May 1973. Serge Friant, president of the David Bowie Fan Club Toulouse ${ }^{20}$, confided to me that the whole of the exhibition space was created specifically for the show. The showcases 
along the central axis of the exhibition space were devoted to a selection of documents related to Bowie's discography from a private collection: collectibles such as album sleeves, contemporary articles documenting the way to Ziggy Stardust and the subsequent rise of Bowie during 1972-73, and more recent ones such as an interview with Mick Rock in Rolling Stone ${ }^{21}$. Above the showcases were hanging three unique guitars: they were specially made by Pierre Gautier (the models could be ordered for purchase). The exhibition also featured four videos in a dedicated small structure resembling a summer shed within the exhibition space. It showcased some original and rare vinyls and four videos were screening in loop: one video was generously offered by the CNES and three others were mounted by the Fan Club.

The exhibition came with a catalogue, Life on Mars David Bowie_Shot by Mick Rock, prefaced by Mick Rock and Philippe Delécluse. It includes a reproduction of all forty photographs and their caption complied in an index. There were various events accompanying the exhibition, such as the opening reception in the presence of Mick Rock himself and the conference organized at the University of Toulouse 2 Jean Jaurès. Limited prints could also be purchased by correspondence.

The exhibition thus provided for a fertile connection among multiple strains of collections: Mick Rock's superb prints, the documents from the private collection, the video installation and the academic interest all combined to pay homage to the indefatigable and exceptional creative that was David Bowie. As Philippe Delécluse has reminded visitors in his preface: "[Bowie and others of his kind] have changed the world so that we, regular people, could live in peace... or close to it: the fight goes on. Against all extremists that would like to see the Aliens disappear."

\section{BIBLIOGRAPHY}

Hoskyns, Barney. Mick Rock interview. In Rock 2016: 27-32.

Mick Rock. The Rise of David Bowie, 1972-1973. Taschen, 2016.

Mick Rock and Philippe Delécluse. Life on Mars David Bowie_Shot by Mick Rock_. Exhibition catalogue, Le Multiple, Toulouse, 2016.

The Fashion Book. Phaidon Press Limited, 2014.

\section{NOTES}

1. http://www.imaginationsfertiles.fr/multiple/

2. http://rencontres-arles-photo.tv/en/advanced-search/results\#total-records

3. In an interview Rock mentions that he was often the only photographer present at the concerts: http://www.rollingstone.fr/david-bowie-par-mick-rock/

4. On his website, what seems to be the original version of this photograph by his daughter is dated 2010: http://www.mickrock.com/about/ 
5. The text was displayed in French only, but the catalogue carries the English version too.

6. Further partners included the City Council of Toulouse and Toulouse Métropole among others.

7. I owe a debt of gratitude to my colleague Emeline Jouve for subtly drawing my attention to the exhibition in the first place. The one-day conference on 2 December 2016 was organized by Nathalie Vincent-Arnaud (Toulouse-Jean Jaurès, CAS), Emeline Jouve (Albi-Champollion, CAS), Philippe Birgy (Toulouse-Jean Jaurès, CAS) and David Roche (Toulouse-Jean Jaurès, CAS).

8. The date of the Farewell concert, 3 July 1973 is, correctly given in the Taschen edition, the exhibition catalogue read 4 July 1973 since it probably refers to the afterparty.

9. The video has recently been reedited by Rock on the request of Bowie's record label EMI.

10. Rock, in an interview with Stella Aaron to Rolling Stone (Special Edition David Bowie, No 25: 22 ), in early 2016, on display at the exhibition, gives "two days after his first shot of Bowie" as the precise date, that is 19 March 1972.

11. https://www.mickrock.com/about/

12. https://www.youtube.com/watch?v=v--IqqusnNQ

13. https://www.youtube.com/watch?v=CGQ06zpVzt8

14. https://www.youtube.com/watch? $v=6$ VrqCBsbeuc

15. https://www.youtube.com/watch?v=cYMCLz5PQVw

16. https://fashionunited.uk/news/fashion/fashion-s-unsung-designers-bowie-s-freddieburretti/2016012719192

17. https://www.youtube.com/watch?v=4MrP83SqT9E

18. https://www.mickrock.com/kabuki/

19. For a well-documented article on the evolution of Bowie's style and his impact on the fashion world, see http://www.lesinrocks.com/2016/01/11/musique/bowie-self-made-mode-11797101/ by Nelly Kaprièlian.

20. https://fr-fr.facebook.com/davidbowiefanclubtoulouse/

21. Read as well: http://www.rollingstone.fr/david-bowie-par-mick-rock/

\section{INDEX}

Subjects: Photography

Mots-clés: David Bowie, Life on Mars, photographie, les années 1970, musique glam rock

Keywords: David Bowie, Life on Mars, photography, 1970s, glam rock music

\section{AUTHORS}

DANIEL HUBER

Maître de conférences

Université de Toulouse

daniel.huber@univ-tlse2.fr 